\title{
MONETIZATION OF ENVIRONMENTAL EXTERNALITIES FOR ECONOMIC ANALYSIS. CASE STUDY: URBAN MOBILITY IN ORADEA
}

\author{
Ovidiu - Vasile GULER, Corina BOLOȘ \\ University of Oradea, Doctoral School of Economic Sciences, Faculty of Economic \\ Sciences, The Finance - Accounting Department, Oradea, Romania \\ guler.ovidiu@gmail.com,boloscorina@gmail.com
}

\begin{abstract}
One of the main limitations identified in the specialized literature is represented by the insufficient quantification of the environmental externalities in the process of carrying out the economic analysis within the cost-benefit analysis for the urban mobility projects specific to the local public authorities. Cost-benefit analysis is an essential tool for prioritizing public investment. The research methodology used in this paper includes data analysis, observation and data modeling. The purpose of this paper is represented by the analysis of the monetization of the environmental externalities specific to the economic analysis of the projects in the field of urban mobility of Oradea Municipality. Economic analysis involves estimating the contribution of a public investment to the economic well-being of a city, region or country and is very important because it also includes the economic and social benefits of an investment. In Romania, the economic analysis is mandatory for all investment projects that involve conducting a feasibility study. Socio-economic analysis involves making fiscal corrections, corrections for externalities and transformation into accounting prices. Externalities can be positive or negative and can be caused by production or consumption. Negative externality is an external cost and positive externality is an external benefit. In performing a cost-benefit analysis when an investment is analyzed from an economic point of view, externalities must be quantified from a monetary point of view. Shadow prices are monetary values attributed to externalities. These shadow prices are used in economic analysis specific to cost-benefit analysis. Shadow prices are assigned when market prices are not known accurately or when it is difficult to quantify certain costs. An example of a shadow price is the value attributed to the emission cost of one tonne of carbon dioxide. A limitation of this paper is represented by the fact that we analyzed only the environmental externalities specific to urban mobility. In future works I want to expand the research of other externalities and to carry out the economic analysis at the level of investment projects of local importance.
\end{abstract}

Keywords: economic analysis, monetization; externalities, urban mobility, public investments, shadow price

JEL classification: $H 72 ; H 83 ; Q 56 ; R 53$

\section{Introduction}

In this paper we aim to analyze the importance of monetizing environmental externalities. For example, I will present the savings resulting from the implementation of 8 projects in the field of urban mobility in Oradea. The deadline for completion of these projects is 2023 . 
The purpose of this paper is to create an indicator that analyzes the monetization of environmental externalities for a city. Thus, this paper wants to improve the specialized literature in the field of financial resources allocation, taking into account the realization of a correct economic analysis and the awareness of the socio - economic impact of the projects.

In Romania, the economic analysis is mandatory for all investment projects that involve conducting a feasibility study, in accordance with Government Decision no. 907 of 2016, Annex 4 - Feasibility study, section 4.7 Economic analysis. At the same time, the economic analysis is mandatory at the level of projects financed from European Union funds.

Externalities can be positive or negative and can be caused by production or consumption. Negative externality is an external cost and positive externality is an external benefit. In performing a cost-benefit analysis when an investment is analyzed from an economic point of view, externalities must be quantified from a monetary point of view. Positive externalities of consumption can be represented by: increasing the level of education of individuals (positive impact on society by increasing living standards or lowering the unemployment rate), the use of applications that transmit data that can be used by other citizens.

Shadow prices are monetary values attributed to externalities. These shadow prices are used in economic analysis specific to cost-benefit analysis. Shadow prices are assigned when market prices are not known accurately or when it is difficult to quantify certain costs.

Economic analysis involves estimating the contribution of a public investment to the economic well-being of a city, region or country and is very important because it also includes the economic and social benefits of an investment. Socioeconomic analysis involves making fiscal corrections, corrections for externalities and transformation into accounting prices.

The cost / benefit analysis involves performing an analysis between the total investment cost following the socio-economic analysis of the project. Thus, the total value of the project is adjusted to economic values from financial values by using conversion factors. The cost / benefit analysis for projects financed from European funds is carried out in compliance with the provisions of the Guide for Cost - Benefit Analysis of investment projects, a guide developed by the European Commission, Directorate-General for Regional Policy.

The municipality of Oradea has a policy for the development of urban mobility in accordance with the protection of the environment. Thus, the main purpose of urban mobility is to improve the mobility and transport of people in Oradea while environmental protection involves reducing greenhouse gas emissions.

The problem from which this paper starts is represented by the lack of sufficient quantification of environmental externalities in the analysis of projects in the field of urban mobility of local importance.

\section{Literature review}

Economic analysis is a subject studied in the literature. Economic analysis is essential for selecting projects that are economically and socially efficient.

Sunstein Cass (2017) wonders if people think better in a foreign language and the answer is that to some extent yes. Thus, cost / benefit analysis can reduce the risk caused by certain institutions that can cause serious errors. Geistfeld Mark (2018) 
makes a connection between welfare ("welfarism") and cost-benefit analysis. Thus, all potential losses and gains are included in the cost-benefit analysis of the change in welfare.

Revesz Richard (2016) presents the existing debate in academia on the need and feasibility of conducting cost / benefit analysis of externalities in the financial field. Thus, externalities in the field of environmental protection are quantified in the cost / benefit analysis but the quantification and monetization of externalities imposed by financial regulations is much more difficult.

Sinden Amy (2016) mentions the importance of cost-benefit analysis considering that it is one of the three ways to achieve environmental protection objectives along with feasibility study and health standards. Thus, it is a decision-making technique that takes into account the costs and benefits of an action.

Masur Jonathan and Eric Posner (2011) consider that regulatory agencies do not take sufficient account of the problem of lack of employment. Thus, the feasibility analyzes present the problem of employment in a summary and theoretical way.

The main difference between financial analysis indicators and economic analysis indicators is that financial analysis is performed at the level of financial flows while economic analysis involves assessing the impact on society as a whole. Economic analysis is very important because the effects of a project cannot be quantified only at the monetary level, the effects of a project must be analyzed as a whole from the point of view of the socio-economic impact.

Birdsall Nancy and Griffin Charles (1993) believe that population growth leads to the existence of certain negative externalities such as increased pollution, global warming or increased living standards for certain social categories. Thus, in this paper will be analyzed the negative externalities generated by urban pollution.

Eskeland Gunnar (2000) considers that negative externalities can be reduced not only by changing consumption habits but also by carrying out activities that are less polluting by consumers, producers and government. At the same time, it proposes the introduction of taxes to be applied to all polluters regardless of how rich or poor they are. I agree with this approach and since this idea was enunciated in 2000, it has been applied at the level of the European Union.

Florio Massimo (2006) considers that investments in infrastructure in the member states of the European Union are necessary. For the choice of projects, costbenefit analysis is an important tool, but there are certain problems with shadow pricing or information asymmetry. I consider that the cost-benefit analysis is an essential tool for prioritizing investment projects.

Zhao Shirong (2020) emphasizes the need for the correct assessment of shadow prices so that environmental regulators can make the right decisions. At the same time, an important goal is to combat global warming and reduce greenhouse gas emissions.

\section{Externalities and shadow prices}

Externalities can be positive or negative and can be caused by production or consumption. Negative externality is an external cost and positive externality is an external benefit. In performing a cost-benefit analysis when an investment is analyzed from an economic point of view, externalities must be quantified from a monetary point of view. If the financial analysis of an investment is made from the point of view of cash flows, the economic analysis includes, in addition to cash flows, externalities (positive and negative). 
According to the CBA guide published by the European Commission (2014), externalities do not have an impact on the transactions that take place between the producer and the users but have an impact on a third party that does not receive any compensation. Thus, the CBA guide (p. 61) defines externality as a cost or benefit that over a third party without monetary compensation.

Examples of negative externalities generated by production are represented by pollution (air pollution, noise pollution, water pollution, soil pollution, light pollution, municipal waste, nuclear waste) that cause climate change. Negative externalities caused by consumption can be represented by traffic jams that have as a negative effect the increase of pollution and the increase of the time that people spend in traffic (decrease of the quality of life). The city of Oradea has taken a series of measures to reduce traffic jams so as to reduce pollution and time spent in traffic.

The CBA guide prepared by the European Commission (2014) mentions several externalities (p. 88) that will be analyzed in the cost-benefit analysis for projects financed from European funds. These externalities can be positive or negative and are represented by: travel time, operating cost of vehicles, accidents, noise emissions, air pollution, greenhouse gas emissions. In carrying out the cost-benefit analysis, these externalities will be monetized.

Positive externalities are found in the literature under various names such as external profit or external economy. The positive externalities of production are represented by the benefits at the level of the society created in the production of some goods or services and which are not compensated. Examples of positive production externalities are represented by the benefits brought for the progress of the research - development - innovation society. Other examples are the creation of free software or the restoration of historical monuments. In Oradea, we want to restore as many historical monuments as possible.

Positive externalities of consumption can be represented by: increasing the level of education of individuals (positive impact on society by increasing living standards or lowering the unemployment rate), the use of applications that transmit data that can be used by other citizens.

Regarding the current society, externalities are analyzed mostly from the point of view of the environmental cost. The European Union and the democratic states (United States, Canada, Australia or Japan) are the engine of the fight against pollution and climate change. Two important moments were represented by the Kyoto Protocol, Japan in 1997 and the Paris Agreement in 2015 by which the states of the world want to reduce pollution. Pollution has harmful effects (negative externalities) on people because due to pollution people get sick and the costs of hospitalization and medical treatments increase. Also due to diseases caused by pollution, some people lose their ability to work, ie additional costs for society. Since Romania's accession to the European Union (2007) in our country began to be aware of the importance of reducing pollution by allocating structural funds for areas related to reducing pollution: waste management, construction of railways, subway, increasing the use of public transport through procurement of trams or electric buses.

Shadow prices are monetary values attributed to externalities. These shadow prices are used in economic analysis specific to cost-benefit analysis. Shadow prices are assigned when market prices are not known accurately or when it is difficult to quantify certain costs. An example of a shadow price is the value attributed to the emission cost of one tonne of carbon dioxide. 


\section{Case study: Monetizing the externalities of projects in the field of urban mobility in Oradea}

The municipality of Oradea has a policy for the development of urban mobility in accordance with the protection of the environment. Thus, the main purpose of urban mobility is to improve the mobility and transport of people in Oradea while environmental protection involves reducing greenhouse gas emissions. Oradea implements 8 projects financed by the Regional Operational Program $2014-2020$, priority axis 4 , investment priority 4.1 , financing axis through which urban mobility is supported. A condition for the projects to be financed is represented by the observance of the rules of sustainable development and the projects must be environmentally friendly.

The method of calculating the costs of greenhouse gas emissions, according to the CBA guide of the European Commission (p. 63) is given by the following calculation formula:

Cost of $\mathrm{GHG}$ emissions $=\mathrm{V}_{\mathrm{GHG}} \times \mathrm{C}_{\mathrm{GHG}}$

Where:

$\mathrm{GHG}=$ greenhouse gas;

$V_{G H G}=$ incremental volume (difference between the version without project and the version with project) measured in carbon dioxide equivalent;

$\mathrm{C}_{\mathrm{GHG}}=$ updated carbon dioxide shadow price for the analysis year.

Table 1: Greenhouse gas savings - percentage (2027 - 2021) in Oradea

\begin{tabular}{|c|c|c|c|c|c|}
\hline \multirow[b]{2}{*}{ Project } & \multicolumn{3}{|c|}{$\begin{array}{c}\text { Greenhouse gas emissions } \\
\text { (tonnes of CO2 equivalent per } \\
\text { year) }\end{array}$} & \multirow{2}{*}{$\begin{array}{c}\text { Greenhouse } \\
\text { gas saving } \\
\text { economy - } \\
\text { absolute } \\
\text { value (2027 - } \\
2021) \text { - } \\
\text { tonnes of } \\
\text { CO2 }\end{array}$} & \multirow{2}{*}{\begin{tabular}{|} 
Greenhou \\
se gas \\
savings - \\
percentag \\
e (2027 - \\
$2021)$
\end{tabular}} \\
\hline & 2017 & 2023 & 2027 & & \\
\hline $\begin{array}{l}\text { Construction of the } \\
\text { new tram line from } \\
\text { Calea Aradului - } \\
\text { Cantemir, Oradea }\end{array}$ & $47,718.50$ & $44,881.80$ & $44,849.20$ & $2,869.30$ & $6.01 \%$ \\
\hline $\begin{array}{l}\text { Underground } \\
\text { passages in Emanuil } \\
\text { Gojdu Square, Oradea } \\
\text { - phase } 1\end{array}$ & $2,192.50$ & $2,037.90$ & $2,036.40$ & 156.10 & $7.12 \%$ \\
\hline $\begin{array}{l}\text { Underground } \\
\text { passages in Emanuil } \\
\text { Gojdu Square, Oradea } \\
\text { - phase } 2\end{array}$ & $2,024.80$ & $1,894.90$ & $1,893.50$ & 131.30 & $6.48 \%$ \\
\hline $\begin{array}{l}\text { Pedestrian areas in } \\
\text { Oradea (Rogerius, } \\
\text { losia and Nufarul) }\end{array}$ & 135.40 & 107.70 & 107.70 & 27.70 & $20.46 \%$ \\
\hline Mobility corridor & $62,931.00$ & $60,388.00$ & $60,723.00$ & $2,208.00$ & $3.51 \%$ \\
\hline
\end{tabular}




\begin{tabular}{|c|c|c|c|c|c|}
\hline $\begin{array}{l}\text { Nufarul - Cantemir, } \\
\text { Oradea }\end{array}$ & & & & & \\
\hline $\begin{array}{l}\text { Acquisition of } 10 \text { trams } \\
\text { - phase } 1\end{array}$ & $47,718.50$ & $45,239.30$ & $45,206.40$ & $2,512.10$ & $5.26 \%$ \\
\hline $\begin{array}{l}\text { Acquisition of } 10 \text { trams } \\
\text { - phase } 2\end{array}$ & $47,718.50$ & $45,239.30$ & $45,206.40$ & $2,512.10$ & $5.26 \%$ \\
\hline $\begin{array}{l}\text { Pedestrian areas in the } \\
\text { central area } \\
\text { (Ferdinand Square, } \\
\text { Aurel Lazar Street, } \\
\text { Libertatii Street and } \\
\text { the left bank area of } \\
\text { Crisul Repede) }\end{array}$ & 619.10 & 452.90 & 452.50 & 166.60 & $26.91 \%$ \\
\hline Total & $211,058.30$ & $200,241.80$ & $200,475.10$ & $10,583.20$ & $5.01 \%$ \\
\hline
\end{tabular}

Source: table made by the author following the analysis of the 8 traffic studies carried out by the Municipality of Oradea

In this table are presented the greenhouse gas savings as a result of the implementation of these 8 projects. There is a reduction of greenhouse gas emissions from 2017 (the year analyzed in traffic studies) to 2027 (the target year of project implementation results) by $5.01 \%$. This complex indicator that shows the reduction of greenhouse gases in Oradea through these 8 projects involves savings of $10,583.20$ tons per year of carbon dioxide.

In accordance with the analysis of the European Investment Bank (2013, p. 25) on environmental externalities, several scenarios were developed to evaluate the monetization of environmental externalities with values between 40 euros / tonne of carbon dioxide equivalent (the central scenario for 2020) and 231 euro / ton of carbon dioxide equivalent (high scenario for 2050). This assessment takes into account the damage caused by these greenhouse gas emissions, damage to both human health and other relevant issues. In this analysis, the value of 96 euro / ton of carbon dioxide equivalent was taken into account (high scenario for 2030). The 2030 scenario was considered because it is the closest year in the analysis of the European Investment Bank in relation to 2027, the target year of the indicators from the 8 traffic studies. Thus, this price per ton is multiplied by the amount of carbon dioxide saved as a result of the implementation of these projects. As can be seen, the annual saving as a result of the monetization of this positive externality is represented by $1,015,987.20$ euros. Therefore, in 10 years only from the carbon dioxide economy 10.15 million euros are saved. We must say that pollution in the city brings increased costs to the health of the population and reducing pollution has a beneficial impact from a socio-economic point of view.

As can be seen from this table, not all projects have the same impact on the savings resulting from the reduction of greenhouse gas emissions. Thus, projects involving the movement of private cars involve higher carbon dioxide emissions while projects involving the movement of pedestrians involve lower carbon dioxide emissions. 
Table 2: Positive environmental externalities as a result of the implementation of the 8 urban mobility projects in Oradea

\begin{tabular}{|l|r|r|r|r|}
\hline \multicolumn{1}{|c|}{ Project } & $\begin{array}{c}\text { Greenhouse } \\
\text { gas saving } \\
\text { economy - } \\
\text { absolute value } \\
\text { (2027 - 2021) - } \\
\text { tonnes of CO2 }\end{array}$ & $\begin{array}{c}\text { Greenhouse } \\
\text { gas savings } \\
\text { percentage } \\
\text { (2027 - 2021) }\end{array}$ & $\begin{array}{c}\text { The cost of } \\
\text { one tonne } \\
\text { of CO2 } \\
\text { equivalent } \\
\text { (euro) }\end{array}$ & $\begin{array}{c}\text { Annual } \\
\text { economy } \\
\text { (euro) }\end{array}$ \\
\hline $\begin{array}{l}\text { Construction of the new tram } \\
\text { line from Calea Aradului - } \\
\text { Cantemir, Oradea }\end{array}$ & $2,869.30$ & $6.01 \%$ & 96.00 & $275,452.80$ \\
\hline $\begin{array}{l}\text { Underground passages in } \\
\text { Emanuil Gojdu Square, } \\
\text { Oradea - phase 1 }\end{array}$ & 156.10 & $7.12 \%$ & 96.00 & $14,985.60$ \\
\hline $\begin{array}{l}\text { Underground passages in } \\
\text { Emanuil Gojdu Square, } \\
\text { Oradea - phase 2 }\end{array}$ & 131.30 & $6.48 \%$ & 96.00 & $12,604.80$ \\
\hline $\begin{array}{l}\text { Pedestrian areas in Oradea } \\
\text { (Rogerius, losia and Nufarul) }\end{array}$ & 27.70 & $20.46 \%$ & 96.00 & $2,659.20$ \\
\hline $\begin{array}{l}\text { Mobility corridor Nufarul - } \\
\text { Cantemir, Oradea }\end{array}$ & $2,208.00$ & $3.51 \%$ & 96.00 & $211,968.00$ \\
\hline $\begin{array}{l}\text { Acquisition of 10 trams - } \\
\text { phase 1 }\end{array}$ & $2,512.10$ & $5.26 \%$ & 96.00 & $241,161.60$ \\
\hline $\begin{array}{l}\text { Acquisition of 10 trams - } \\
\text { phase 2 }\end{array}$ & $2,512.10$ & $5.26 \%$ & 96.00 & $241,161.60$ \\
\hline $\begin{array}{l}\text { Pedestrian areas in the } \\
\text { central area (Ferdinand } \\
\text { Square, Aurel Lazar Street, } \\
\text { Libertatii Street and the left } \\
\text { bank area of Crisul Repede) }\end{array}$ & 166.60 & $26.91 \%$ & 96.00 & $15,993.60$ \\
\hline & $\mathbf{1 0 , 5 8 3 . 2 0}$ & $\mathbf{5 . 0 1 \%}$ & 96.00 & $\mathbf{1 , 0 1 5 , 9 8 7 . 2 0}$ \\
\hline
\end{tabular}

Source: table made by the author following the analysis of the 8 traffic studies carried out by the Municipality of Oradea

The two projects that create pedestrian routes involve reducing greenhouse gas emissions by over $20 \%$ but in absolute terms the annual savings (calculated according to the specific methodology) is lower than the savings from projects that provide for the purchase of trams.

The $5 \%$ reduction of greenhouse gas emissions is not enough, and these projects must be continued with other projects regarding the acquisition of trams and buses, the construction of new underground passages to streamline traffic, the construction of park \& ride parking lots at the edge. the city, the construction of bicycle lanes, the creation of new pedestrian routes as well as the encouragement of increasing the average number of passengers in private cars. 
Table 3: Analysis of the variation of annual savings resulting from the monetization of environmental externalities

\begin{tabular}{|l|r|}
\hline Project & Annual economy in 2027 (euro) \\
\hline $\begin{array}{l}\text { Portfolio consisting of } 8 \text { mobility projects - } \\
\text { project scenario }\end{array}$ & $1,015,987.20$ \\
\hline Variation $+1 \%$ & $1,026,147.07$ \\
\hline Variation $-1 \%$ & $1,005,827.33$ \\
\hline Variation $+5 \%$ & $1,066,786.56$ \\
\hline Variation $-5 \%$ & $965,187.84$ \\
\hline Variation $+10 \%$ & $1,117,585.92$ \\
\hline Variation $-10 \%$ & $914,388.48$ \\
\hline Variation $+25 \%$ & $1,269,984.00$ \\
\hline Variation $-25 \%$ & $761,990.40$ \\
\hline
\end{tabular}

Source: table made by the author following the analysis of the 8 traffic studies carried out by the Municipality of Oradea

At the same time, in table no. 3 an analysis is made of the variation of the registered savings as a result of the monetization of the environmental externalities. This analysis involves 8 scenarios of positive and negative variation $(1 \%, 5 \%, 10 \%$ and $25 \%)$. Thus, through these 8 projects in the field of urban mobility, superior results could be obtained, but also inferior to those resulting from the traffic study. Thus, greenhouse gas emissions could be reduced through complementary measures such as increasing the frequency of public transport, increasing the average number of people in private vehicles or using more nonmotorized transport (bicycles, scooters, walking).

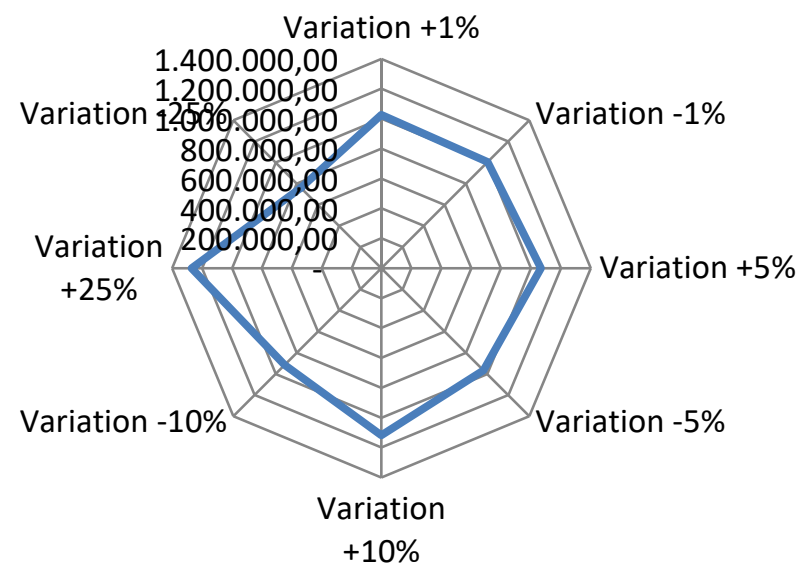

Annual economy in 2027 (euro)

Figure 1: Analysis of the variation of annual savings resulting from the monetization of environmental externalities

Source: figure made by the author following the analysis of the 8 traffic studies carried out by the Municipality of Oradea 


\section{Conclusions}

This paper presents the monetization of the environmental externalities of the 8 urban mobility projects financed by the Regional Operational Program $2014-2020$. There is a reduction of greenhouse gas emissions from 2017 (the year analyzed in traffic studies) to 2027 (the target year of project implementation results) by $5.01 \%$. This complex indicator that shows the reduction of greenhouse gases in Oradea through these 8 projects involves savings of 10,583.20 tons per year of carbon dioxide.

The purpose of this paper is represented by the analysis of the monetization of the environmental externalities specific to the economic analysis of the projects in the field of urban mobility of Oradea Municipality. The municipality of Oradea has a policy for the development of urban mobility in accordance with the protection of the environment. Thus, the main purpose of urban mobility is to improve the mobility and transport of people in Oradea while environmental protection involves reducing greenhouse gas emissions. The problem from which this paper starts is represented by the lack of sufficient quantification of environmental externalities in the analysis of projects in the field of urban mobility of local importance.

In accordance with the analysis of the European Investment Bank (2013, p. 25) on environmental externalities, several scenarios were developed to evaluate the monetization of environmental externalities with values between 40 euros / tonne of carbon dioxide equivalent (the central scenario for 2020) and 231 euro / ton of carbon dioxide equivalent (high scenario for 2050). This assessment takes into account the damage caused by these greenhouse gas emissions, damage to both human health and other relevant issues. In this analysis, the value of 96 euro / ton of carbon dioxide equivalent was taken into account (high scenario for 2030). The 2030 scenario was considered because it is the closest year in the analysis of the European Investment Bank in relation to 2027, the target year of the indicators from the 8 traffic studies. Thus, this price per ton is multiplied by the amount of carbon dioxide saved as a result of the implementation of these projects. As can be seen, the annual saving as a result of the monetization of this positive externality is represented by $1,015,987.20$ euros. Therefore, in 10 years only from the carbon dioxide economy 10.15 million euros are saved. We must say that pollution in the city brings increased costs to the health of the population and reducing pollution has a beneficial impact from a socio-economic point of view.

Regarding the current society, externalities are analyzed mostly from the point of view of the environmental cost. The European Union and the democratic states (United States, Canada, Australia or Japan) are the engine of the fight against pollution and climate change. Two important moments were represented by the Kyoto Protocol, Japan in 1997 and the Paris Agreement in 2015 by which the states of the world want to reduce pollution. Pollution has harmful effects (negative externalities) on people because due to pollution people get sick and the costs of hospitalization and medical treatments increase. Also due to diseases caused by pollution, some people lose their ability to work, ie additional costs for society. Since Romania's accession to the European Union (2007) in our country began to be aware of the importance of reducing pollution by allocating structural funds for areas related to reducing pollution: waste management, construction of railways, subway, increasing the use of public transport through procurement of trams or electric buses. 
A limitation of this paper is represented by the fact that I analyzed only the environmental externalities specific to urban mobility. In future works I want to expand the research of other externalities and to carry out the economic analysis at the level of investment projects of local importance.

\section{References:}

1. Boloş Marcel loan (2007), Buget şi trezorerie publică, Editura Universităţii Oradea

2. Birdsall Nancy, Griffin Charles (1993), Population growth, externalities and poverty, The World Bank, Working Paper, Available at SSRN: https://papers.ssrn.com/sol3/papers.cfm?abstract_id=3351859

3. Czichowsky Christoph, Muhle-Karbe Johannes, Schachermayer Walter (2013) Transaction Costs and Shadow Prices in Discrete Time, Available at SSRN: https://papers.ssrn.com/sol3/papers.cfm?abstract_id=2342201

4. Eskeland Gunnar (2000), Externalities and Production Efficiency, The World Bank, Development Research Group, Public Economics

5. Florio Massimo (2006), Multi-Government Cost-Benefit Analysis: Shadow Prices and Incentives, Available at SSRN:

https://papers.ssrn.com/sol3/papers.cfm?abstract_id=3200965

6. Geistfeld Mark (2018), Cost-Benefit Analysis Outside of Welfarism, Available at SSRN: https://papers.ssrn.com/sol3/papers.cfm?abstract_id=3172315 7. Masur Jonathan și Posner Eric (2011), Regulation, Unemployment, and Cost-Benefit Analysis, Available at SSRN: https://papers.ssrn.com/sol3/papers.cfm?abstract_id=1920441

8. Revesz Richard (2016), Cost-Benefit Analysis and the Structure of the Administrative State: The Case of Financial Services Regulation, Available at SSRN: https://papers.ssrn.com/sol3/papers.cfm?abstract_id=2733713

9. Sinden Amy (2016), Cost-Benefit Analysis, Available at SSRN: https://papers.ssrn.com/sol3/papers.cfm?abstract_id=2831832

10. Sunstein Cass, Is Cost-Benefit Analysis a Foreign Language?, 2017, Available at https://papers.ssrn.com/sol3/papers.cfm?abstract_id=2893401

11. Zhao Shirong (2020), The Shadow Prices of $\mathrm{CO}_{2}, \overline{S O}_{2}$ and $\mathrm{NO}$ x for U.S. Coal Power Industry 2010-2017: A Convex Quantile Regression Method Available at SSRN: https://papers.ssrn.com/sol3/papers.cfm?abstract_id=3692709

12. European Comission (2014), Guide to Cost - Benefit Analysis of Investment Projects, https://ec.europa.eu/regional_policy/sources/docgener/studies/pdf/cba_guide.pdf 13. European Investment Bank (2013), The Economic Appraisal of Investment Projects at the EIB, Available at: https://www.eib.org/attachments/thematic/economic_appraisal_of_investment_proj ects_en.pdf

14. HG Romania nr. 907 / 2016 on the stages of elaboration and the content framework of the technical-economic documentation related to the objectives / investment projects financed from public funds

15. Traffic studies carried out by The Municipality of Oradea for 8 urban mobility projects (2018)

The work was supported by University of Oradea, Doctoral School of Economic Sciences 